\author{
AgniesZKa Brzosko-Sermak \\ Uniwersytet Pedagogiczny w Krakowie, Polska - Pedagogical University of Cracow, Poland \\ StaWOMIR DOROCKI \\ Uniwersytet Pedagogiczny w Krakowie, Polska - Pedagogical University of Cracow, Poland
}

\title{
Znaczenie turystyki w rozwoju Krynicy-Zdroju
}

\section{The Importance of Tourism in the Development of Krynica-Zdrój}

Streszczenie: Krynica-Zdrój od lat opiera swój rozwój na turystyce. W powyższym podejściu ważne są przedsiębiorcza i aktywna postawa lokalnych władz, konkretny plan działań zapisany w dokumentach strategicznych oraz stała analiza zmieniającego się profilu turysty. Celem niniejszej pracy było ukazanie obecnego znaczenia turystyki w rozwoju Krynicy-Zdroju oraz zbadanie preferencji, zadowolenia i opinii turystów, którzy na przestrzeni ostatnich lat odwiedzają to uzdrowisko. Wykorzystane metody badawcze to badania ankietowe przeprowadzone wśród turystów w roku 2013 i 2017 oraz analiza dokumentów strategicznych. Uzyskane wyniki wskazują, że turystyka odgrywa decydującą rolę w rozwoju gospodarczym, przestrzennym i funkcjonalnym Krynicy-Zdroju. Bogata i zróżnicowana oferta kurortu, w tym kreowana przez lokalne władze, stanowi jego silną przewagę konkurencyjną. Zmienia się jednak profil turysty i charakter wizyt, pomimo że walory zdrojowe i krajobrazowe na przestrzeni lat pozostają głównym impulsem przyjazdów.

\begin{abstract}
Krynica-Zdrój has been developing its tourism for years. This approach has to be supported by the entrepreneurial and active attitude of local authorities documented in the strategic documents and a constant analysis of the changing profile of tourists. The aim of this work was to present the current importance of tourism in the development of Krynica-Zdrój and to explore the preferences, satisfaction and opinion of tourists who visited Krynica-Zdrój over the last years. The research methods used were the survey of tourists $(2013,2017)$ and analysis of strategic documents. The results of both analyses show that tourism plays a decisive role in the economic, spatial and functional development of Krynica-Zdrój. Numerous and varied values are a strong competitive advantage and local authorities are very active in differentiating the offer addressed to the visitors. However, the profile of the tourist and the nature of the visit is changing, despite the fact that the spa and landscape values over the years remain the main impetus for arrivals.
\end{abstract}

Słowa kluczowe: Krynica-Zdrój; rozwój społeczno-ekonomiczny; samorząd; spa; turystyka

Keywords: Krynica-Zdrój; self-government; socio-economic development; SPA; tourism

Otrzymano: 16 listopada 2017

Received: 16 November 2017

Zaakceptowano: 25 maja 2018

Accepted: 25 May 2018 


\section{Sugerowana cytacja/Suggested citation:}

Brzosko-Sermak, A., Dorocki, S. (2018).Znaczenie turystyki w rozwoju Krynicy-Zdroju. Przedsiębiorczość - Edukacja [Entrepreneurship - Education], 14, 313-328. DOI: 10.24917/20833296.14.23

\section{Wstęp}

Obecnie miasta, które chcą się rozwijać w dynamiczny sposób, muszą ciągle poszukiwać rozwiązań zapewniających im przewagę konkurencyjną i jednocześnie stawiać czoła licznym problemom gospodarczym oraz coraz trudniejszej sytuacji demograficznej. W pierwszym rzędzie biorą pod uwagę już posiadane zasoby, które przy umiejętnym wykorzystaniu, zagospodarowaniu oraz dzięki odpowiedniemu marketingowi mogą z sukcesem stanowić główne siły napędowe lokalnej gospodarki (Brzosko-Sermak i in., 2015). Wiele miast rozwija się dzięki turystyce, jednak nie wszystkie są w stanie zapewnić sobie w ten sposób trwały rozwój (Brzosko-Sermak, Płaziak, 2017). Przykład Krynicy-Zdroju pokazuje, że jest to możliwe, ważne są jednak przedsiębiorcza i aktywna postawa władz lokalnych, konkretny plan działań zapisany w dokumentach strategicznych oraz stała analiza zmieniającego się profilu turysty (Dorocki, Borowiec, 2014).

Przedmiotem niniejszej pracy jest gmina miejsko-wiejska Krynica-Zdrój, położona we wschodniej części Beskidu Sądeckiego, na zachodnim skraju Beskidu Niskiego. Znajduje się ona w południowo-wschodniej części województwa małopolskiego, w powiecie nowosądeckim, $32 \mathrm{~km}$ na południowy wschód od Nowego Sącza. Największą popularność wśród turystów zyskała ona dzięki funkcji uzdrowiskowej miasta (status uzdrowiska górskiego), opierającej się przede wszystkim na źródłach wód leczniczych. Ponadto gmina wyróżnia się licznymi walorami, które nadają jej charakter turystyczno-wypoczynkowy, atrakcyjny zarówno dla kuracjuszy, jak i dla turystów (Dorocki, 1999).

Celem pracy stało się ukazanie obecnego znaczenia turystyki w rozwoju Krynicy-Zdroju na podstawie analizy dokumentów strategicznych prezentujących kierunki rozwoju miasta, wyznaczone przez władze na najbliższe kilka, a nawet kilkanaście lat. Równorzędnie ważnym celem było zbadanie preferencji, zadowolenia i opinii turystów, którzy na przestrzeni ostatnich lat odwiedzili Krynicę-Zdrój. Wyniki obu powyższych analiz pokazują, jak ważną funkcję dla rozwoju miasta pełni turystyka oraz czy władze trafnie ten rozwój planują, biorąc pod uwagę ulegający ciągłym zmianom profil turysty.

Analiza dokumentów strategicznych Krynicy-Zdroju objęła badanie zapisów aktualnych (stan na 2017 r.), zatwierdzonych strategii rozwoju miasta, a w szczególności odwołań bezpośrednio do turystyki jako motoru tego rozwoju. Natomiast badania ankietowe mające na celu zbadanie znaczenia turystyki w rozwoju Krynicy-Zdroju zostały przeprowadzone w roku 2013 i 2017. W obu przypadkach trwały one po pięć dni (na przełomie maja i czerwca) i został w nich zastosowany ten sam formularz pytań. Respondentami byli przypadkowo napotkani turyści w obrębie całego miasta. W 2013 r. udało się uzyskać odpowiedzi od 538, a w 2017 r. od 494 osób. Zastosowanie takiej samej metodyki dało możliwość porównania wyników na przestrzeni kilku lat, a przede wszystkim - zauważenia pojawiających się tendencji i zmian w postrzeganiu tego słynnego uzdrowiska przez turystów. W 2013 r. badania były prowadzone pod kierunkiem dr M. Borowiec-Gabryś i dr. S. Dorockiego (Dorocki, Borowiec, 2014), a w 2017 r. - pod kierunkiem dr A. Brzosko-Sermak i dr. S. Dorockiego. 
Oferta turystyczna Krynicy-Zdroju

Od przeszło dwóch stuleci Krynica-Zdrój zaliczana jest do grona najbardziej liczących się krajowych i europejskich kurortów. W ciągu tych lat, pomimo zmieniających się uwarunkowań politycznych i gospodarczych, odnotowała znaczący rozwój społeczno-gospodarczy. Widoczne jest to zarówno w infrastrukturze leczniczej, obejmującej obiekty budownictwa zdrojowego (np. pijalnie wód), sanatoria oraz obiekty lecznicze, jak i w infrastrukturze związanej z przemysłem wód mineralnych (Buczek, Quirini-Popławski, 2009). Innym przejawem rozwoju kurortu jest powstała na jego terenie infrastruktura turystyczna i sportowa (Dorocki, Brzegowy, 2013a). Już od początku funkcjonowania uzdrowiska propagowana była moda na aktywny wypoczynek, który miał wspomagać proces rekonwalescencji (Dorocki, Brzegowy, 2013b). Doprowadziło to na początku XX w. do powstania w Krynicy rozbudowanej bazy sportowo-turystycznej. Na terenie miasta utworzono lodowisko, korty tenisowe, skocznie narciarskie, tor saneczkowy oraz kolejkę na Górę Parkową. W otaczających Krynicę górach uruchomiono też schroniska turystyczne (Dorocki, Brzegowy, 2015). Rozbudowana infrastruktura dla uprawiania sportów zimowych oraz organizacja licznych zimowych imprez sportowych o zasięgu międzynarodowym zaowocowały nadaniem w okresie międzywojennym miastu miana „zimowej stolicy Polski” (Dorocki, 2016).

W okresie powojennym Krynica rozwijała się głównie dzięki funkcjom uzdrowiskowo-leczniczym. Powstały wówczas liczne obiekty sanatoryjne i wypoczynkowe. W okresie tym miasto rozwijało się przede wszystkim dzięki inwestycjom państwowym oraz branżowym. Obok turystyki leczniczej pewną rolę w funkcjonowaniu kurortu zaczęła odgrywać turystyka górska oraz sportowa. W kurorcie organizowane były liczne zawody sportowe (również o zasięgu międzynarodowym) związane z sezonem zimowym (zawody hokejowe, saneczkowe). Ponadto na terenie miasta funkcjonowały wyciągi narciarskie, przyciągające turystów głównie w okresie ferii zimowych oraz wyjazdów pracowniczych. Jednakże znaczenie tego typu turystyki w odniesieniu do całorocznych funkcji uzdrowiskowych Krynicy było znikome.

Za moment przełomowy w najnowszej historii uzdrowiska przyjąć należy okres transformacji systemowej, związany z drastycznym ograniczeniem środków państwowych na działalność leczniczą oraz konieczność funkcjonowania ośrodków sanatoryjnych w warunkach gospodarki rynkowej (Dorocki, Brzegowy, 2015). Dodatkowym czynnikiem wpływającym na zmianę funkcjonowania kurortu były zmiany strukturalne przemysłu, które doprowadziły do likwidacji wielu krajowych przedsiębiorstw, co z kolei pociągnęło za sobą upadek licznych branżowych obiektów uzdrowiskowych. W wyniku procesu przywracania własności prawowitym właścicielkom pensjonatów i nieruchomości zmianie uległa również cała struktura własności obiektów sanatoryjnych i wypoczynkowych (Bajgier-Kowalska, 2015).

W wyników zaistniałych procesów denacjonalizacji oraz zwrotu majątków prawowitym właścicielom pod koniec XX w. wiele obiektów sanatoryjnych w Krynicy zostało zamkniętych lub sprywatyzowanych. Ponadto pomimo wzrastającego zapotrzebowania na usługi medyczne związane z procesem starzenia się społeczeństwa państwowe nakłady na lecznictwo uzdrowiskowe zostały zmniejszone, a czas oczekiwania na refundowaną kurację sanatoryjną uległ znacznemu wydłużeniu, co wpłynęło na skrócenie czasu kuracji oraz zmniejszenie się liczby kuracjuszy (Drygas, 2013; Dorocki, Brzegowy, 2015). 
Sytuacja ta wymusiła podjęcie działań zmierzających do podniesienia konkurencyjności miasta przez wzbogacenie i dostosowanie jego oferty do zmiany struktury turystów. Spadła wówczas bowiem liczba osób przybywających do uzdrowiska w celach leczniczych, a wzrosła liczba osób młodych, preferujących aktywny wypoczynek oraz usługi typu spa i wellness (Dorocki, Brzegowy, 2013). W ramach inicjatyw podjętych przez samorząd i prywatnych inwestorów w 1997 r. uruchomiono kolej gondolową na Jaworzynę Krynicką, a rok później - halę widowiskowo-sportową. Powstało także wiele obiektów wypoczynkowych o wysokim standardzie, m.in.: hotele: Krynica, Mercury i Prezydent oraz hotel spa dr Ireny Eris (Dorocki, Borowiec, 2014). Innym zauważalnym procesem w uzdrowisku był rozwój usług eventowych oraz tzw. turystyki szkoleniowej i kongresowej. Jednymi z najważniejszych imprez zlokalizowanych w Krynicy są organizowane od 1992 r. międzynarodowe Forum Ekonomiczne w Krynicy oraz Festiwal im. Jana Kiepury. Ponadto na terenie miasta i gminy mają miejsce liczne imprezy sportowe i rozrywkowe, w tym odbywające się od kilku lat konkursy piękności (Wybory Miss Polski i Miss Supranational).

Obserwując obłożenie miejsc noclegowych oraz frekwencję miesięczną turystów, wydaje się, że najważniejszą inwestycja prorozwojową Krynicy jest rozwój infrastruktury do uprawiania sportów zimowych (Čuka i in., 2015). Na terenie miasta funkcjonuje dzisiaj kilkanaście wyciągów narciarskich skupiających się w rejonie Jaworzyny Krynickiej (Czarny Potok), Słotwin i na stokach Góry Krzyżowej. Równocześnie zauważalnym współcześnie procesem w funkcjonowaniu uzdrowiska jest rozwój usług turystycznych na terenach sąsiadujących z kurortem. Spośród miejscowości gminy Krynica-Zdrój największy rozwój infrastruktury turystycznej odnotował sąsiadujący z miastem Tylicz, gdzie zlokalizowane są trzy stacje narciarskie (Dorocki, 2016). W ramach rozwoju infrastruktury sportów zimowych wytyczne zostały trasy narciarstwa biegowego (Czarny Potok, Góra Parkowa, Powroźnik). Potencjał narciarski gminy Krynica wraz z ośrodkami narciarskimi w pobliskim Szczawniku (Muszyna) i Wierchomli (Dorocki, 2007) tworzą zimowy klaster turystyczny (Dorocki, Brzegowy, 2015).

Krynica-Zdrój nieprzerwanie buduje swój potencjał konkurencyjny na wyjątkowych zasobach naturalnych, jakimi są wody mineralne, jednakże główna oferta kurortu skierowana jest obecnie do osób poszukujących aktywnego wypoczynku i relaksu. Pomimo procesu starzenia się społeczeństwa zauważalny jest bowiem proces wzrastania aktywności fizycznej. Dotyczy to zarówno osób młodych, jak i starszych. Krynica, stawiając na rozwój turystyki, stara się kreować swoją markę nie tylko jako uzdrowisko, lecz także jako kurort, w którym to pojęciu zawiera się również wypoczynek (Kopczyńska, 2008). W przyjętym przez Krynicę-Zdrój w 2016 r. logo miasta nie odnajdziemy symboli zdroju i uzdrowiska, ale góry i kolory zimy.

Turystyka w Krynicy-Zdroju rozwija się wielopłaszczyznowo. W pierwszej kolejności jest to aktywny wypoczynek w sezonie zimowym. Drugie miejsce zajmuje wypoczynek i rekreacja w sezonie wakacyjnym oraz w okresach tzw. długich weekendów. Na trzecim miejscu znajdują się turystka eventowa, w tym także biznesowa, motywacyjna i konferencyjna. Ważnym elementem pozostaje turystyka medyczna, jednakże przyjmuje ona obecnie mniej masowy charakter i stanowi uzupełnienie innych form wypoczynku. Zauważalnym procesem jest wzrost zainteresowania turystyką sportową (w tym letnią, np. biegi górskie i kolarstwo) oraz kulinarną. Również ustanowienie w 2016 r. Sanktuarium Matki Bożej Tylickiej w Tyliczu wpłynęło na pojawienie na terenie gminy turystyki religijnej 
(Mróz, 2016). Podobnie bliskość Słowacji oraz atrakcyjność cenowa towarów i usług po stronie polskiej wpływają na wzrost turystyki handlowej. Ponadto uruchomienie kolei gondolowej na Jaworzynę Krynicką wpłynęło na większe zainteresowanie turystyką górską wśród osób starszych oraz osób niezainteresowanych dotychczas turystyką pieszą.

Krynica-Zdrój stanowi zatem współcześnie zarówno ważny ośrodek uzdrowiskowy, jak i znaczące na mapie Polski centrum sportowe i turystyczne. Jest także miejscem rekreacji i wypoczynku, gdzie ważne miejsce zajmują usługi spa i wellness. Warto również wspomnieć, że Krynica to miejsce licznych szkoleń, konferencji i kongresów. Turystka stanowi zatem jeden z najważniejszych sektorów rozwoju miasta i gminy. Pomimo faktu, że w dalszym ciągu Polska pozostaje w tyle w stosunku do rozwoju usług turystycznych w Europie Zachodniej (Čuka i in., 2015), to idea rozwoju Krynicy-Zdroju w oparciu o przemysł turystyczny jest ze wszech miar właściwa.

\section{Turystyka w działalności władz samorządowych Krynicy-Zdroju}

Z jednej strony rozwój Krynicy-Zdroju oparty na znaczących i różnorodnych walorach przyrodniczo-wypoczynkowych oraz długiej historii ośrodka uzdrowiskowego jest w pewien sposób przesądzony i łatwy w realizacji oraz zapewnia pewny sukces. Jednak z drugiej strony efektywne zarządzanie rozwojem lokalnym w silnie konkurencyjnym otoczeniu, w dobie problemów gospodarczych i demograficznych, jest dla władz dużym wyzwaniem (Karwińska, Brzosko-Sermak, 2014). Niezbędne jest zatem wypracowanie sprawnego, uporządkowanego i zintegrowanego systemu podejmowania fundamentalnych i długofalowych decyzji o charakterze rozwojowym. W tym celu uchwalane są dokumenty strategiczne i prowadzony jest marketing terytorialny (Basińska-Zych, 2014). Wśród dokumentów wymienić należy takie opracowania, jak:

- Strategia rozwoju miasta i gminy Krynica-Zdrój, 2013,

- Plan rozwoju uzdrowiska Krynicy-Zdroju na lata 2016-2023, 2016,

- Gminny program rewitalizacji Krynicy-Zdroju na lata 2016-2023, 2017,

- Strategia rozwoju zintegrowanego produktu turystycznego pt. „Perly Doliny Popradu”, 2003,

- Strategia promocji Krynicy-Zdroju, 2011,

- Strategia rozwoju i promocji małopolskiego produktu uzdrowiskowego na lata 20132018.

Podstawowym dokumentem o charakterze strategicznym jest Strategia rozwoju miasta i gminy Krynica-Zdrój. Jej główne funkcje to: porządkowanie podejmowanych decyzji władz samorządowych, pobudzanie i integracja układu podmiotowego regionu, regulacja oraz kontrola, informacja i promocja (Wołowiec, Reśko, 2012). Do głównych założeń w tworzeniu Strategii można zaliczyć: procesowe podejście zarówno do samego etapu formułowania strategii, jak i do jej wdrażania; spójność z systemem polityki rozwoju w całej Unii Europejskiej (zgodność ze strategiami powiatu nowosądeckiego, województwa małopolskiego, Polski i całej Unii); tworzenie programu przez władze samorządowe gminy Krynica-Zdrój; ekspercko-partycypacyjny model przygotowania strategii; charakter długookresowy; jawność w procesie budowania strategii i informowanie na bieżąco mieszkańców o postępach prac; uczestnictwo przedstawicieli poszczególnych interesariuszy (Strategia..., 2013). 
Wizja gminy została przedstawiona w Strategii w następujący sposób: „Gmina Krynica-Zdrój jest atrakcyjnym miejscem do życia ze względu na: prężną, opartą na zdywersyfikowanej turystyce i wyspecjalizowanych usługach gospodarkę, ład przestrzenny i czyste środowisko, unikatowy klimat spędzania czasu wolnego". Cele strategiczne to: dla obszaru przestrzeń - estetyczne i efektywne gospodarowanie przestrzenią w mieście i gminie; dla obszaru gospodarka - wzmocnienie potencjału gospodarczego Krynicy-Zdroju; dla obszaru społeczeństwo - podnoszenie jakości kapitału ludzkiego i społecznego mieszkańców Krynicy-Zdroju. Cel strategiczny wynikający z wagi czynników zewnętrznych to z kolei zwiększenie dostępu do informacji oraz skutecznej współpracy gminy z innymi podmiotami na rzecz rozwoju regionu (Strategia..., 2013: 67-68).

Strategia promocji Krynicy-Zdroju przedstawia ogólną misję następująco: „Gmina uzdrowiskowa Krynica to pierwsza gmina uzdrowiskowa w Karpatach, słynąca staropolską kulturą i gościnnością, przyjazna dla zdrowia i atrakcyjna o każdej porze roku, tworząca szanse godnego życia” (Strategia promocji..., 2011: 8). Kolejna misja zawarta w Strategii promocji odnosi się szczegółowo do turystyki: „Gmina uzdrowiskowa Krynica to perła uzdrowisk polskich będąca międzynarodowym centrum rekreacji, turystyki i rozrywki, propagująca zdrowie, naturę i przygodę oferując gościnność i różnorodność kultur, zapewniając światowe standardy jakości” (Strategia promocji..., 2011: 8). Strategiczna zasada produktów turystycznych Krynicy-Zdroju brzmi: „Krynica, tu jest życie!”, ponieważ można tu „dotknąć i kosztować smaku życia w różnych przejawach: zdrowia, zabawy, sztuki, jedzenia, rozrywki, sportu oraz ryzyka przygody" (Strategia promocji..., 2011: 9).

Cele strategiczne dotyczące realizacji misji zostały określone w Strategii promocji następująco: wzmocnienie wizerunku turystyczno-sportowego gminy, wzrost liczby przyjazdów turystów i podróżnych przy zachowaniu zasad zrównoważonego rozwoju. Bardzo duże znaczenie dla rozwoju turystyki w Krynicy-Zdroju mają: centrum Krynicy-Zdroju, Międzynarodowa Stacja Narciarska „Krynica”, dolina Czarnego Potoku, dolina rzeki Muszynka wraz z łemkowską wioską wakacyjną, Mochnaczką. W analizowanym dokumencie zostały zaproponowane takie produkty turystyczne, jak:

- turystyka aktywna,

- turystyka biznesowa,

- turystyka zdrowotna,

- turystyka przygodowa,

- turystyka wiejska (produkt uzupełniający),

- turystyka przygraniczna,

- turystyka edukacyjna (ścieżki edukacyjne),

- lecznictwo uzdrowiskowe,

- turystyka ekologiczna,

- „natura tourism” (Strategia promocji..., 2011).

W Strategii promocji zaprezentowana została też lista sugerowanych do realizacji przedsięwzięć infrastrukturalnych. Część z nich znalazła się również w Gminnym programie rewitalizacji. Przede wszystkim są to działania ukierunkowane na rewitalizację i uatrakcyjnienie centrum miasta (centrum kongresowe Europa House, park miniatur, kasyno, trasa fontann przy deptaku, aleja żywych atrakcji, baseny geotermalne, amfiteatr letni). Kolejnymi pomysłami były stworzenie łemkowskiej doliny wakacyjnej, historycznego parku tematycznego (Wrota Narodów), przygodowego parku tematycznego, 
krynickiego centrum urody, sportowego parku rodzinnego (w sąsiedztwie lodowiska), parku wodnego, międzynarodowej stacji turystycznej Krynica oraz potraw Krynicy.

W Strategii rozwoju zintegrowanego produktu turystycznego pt. „Perły Doliny Popra$d u$ ” proponuje się podzielić krynickie produkty turystyczne na pięć grup. Są to kolejno: turystyka aktywna i krajobrazowa (rekreacja i wyczyn), sport i natura, zabawa i rozrywki organizowane, turystyka zdrowia (usługi uzdrowiskowe, lecznicze) i odnowy biologicznej - turystyka ciała, turystyka pobytowa, wiejska, ekologiczna, sporty naturalne, turystyka kulturowa, edukacyjna (kultura/sztuka/edukacja), turystyka z obszaru intencive trips konferencje, spotkania integracyjne itd. (Strategia rozwoju zintegrowanego..., 2003).

Plan rozwoju uzdrowiska (2016) zwraca natomiast uwagę na trudności, z jakimi zmagają się gminy, takie jak Krynica-Zdrój. Przede wszystkim chodzi tu o konieczność łącznej i jednoczesnej realizacji zarówno zadań gminy (zaspokajanie potrzeb mieszkańców), jak i zadań związanych z utrzymaniem i rozwojem infrastruktury uzdrowiskowej (przeznaczonej głównie dla osób spoza gminy). Krynica-Zdrój, by sprostać rosnącym wymaganiom rynku, musi kontynuować wprowadzanie rynkowych zasad działania. Najszybsze zmiany powinny obejmować strefę promocji i dystrybucji usług uzdrowiskowych oraz powiązane $z$ nimi procesy akredytacji i certyfikacji.

Jak widać $z$ analizy podstawowych dokumentów strategicznych, w Krynicy-Zdroju silna rola turystyki w obecnym i przyszłym rozwoju miasta jest niezaprzeczalna. Liczne i cenne walory determinują marketing terytorialny, który od lat jest stosowany przez samorząd lokalny badanego miasta. Z jednej strony tak charakterystyczny profil rozwojowy jest dobrodziejstwem, $\mathrm{z}$ drugiej jednak posiadanie statusu uzdrowiska wiąże się równocześnie z realizacją długiej listy obowiązków i zadań, które gmina uzdrowiskowa musi spełnić, aby zagwarantować zewnętrzne warunki pobytu przyjezdnym gościom i kuracjuszom. Na podkreślenie zasługuje również fakt licznych zakazów i obowiązków płynących z zapisów statusu uzdrowiska nakładających na Krynicę-Zdrój liczne ograniczenia rozwoju przestrzennego i dodatkowe wydatki.

\section{Oferta turystyczna Krynicy-Zdroju w opinii turystów}

Analiza struktury respondentów została oparta na badaniu ich wieku, płci, wykształcenia i profilu zawodowego. W 2017 r. wśród przebadanych turystów (ryc. 1A) najliczniejszą grupę, bo 49\%, stanowiły osoby powyżej 64 roku życia, co jest ciekawe, ponieważ w 2013 r. w tym przedziale wiekowym była tylko $1 / 4$ respondentów. Kolejną według udziału grupą badanych byli turyści w wieku 36-64 lata stanowiący niespełna 38\% ankietowanych (w 2013 r. 44\%). Niższe kategorie wiekowe miały już mniej istotne znaczenie. W obu badanych latach wśród respondentów dominowali mężczyźni (ryc. 1B). Można zauważyć związek wieku badanych turystów z uzdrowiskowym charakterem miasta oraz okresem przeprowadzania badań - sezon wiosenno-letni, przed przerwą wakacyjną.

Spośród ankietowanych w 2017 r. najmniej liczną grupę stanowiły osoby z wykształceniem niepełnym wyższym (7\%) i wyższym (8\%) (ryc. 2A), odmiennie niż miało to miejsce w badaniach z 2013 r., gdzie udział tych grup wyniósł 37\%. Wśród respondentów dominowało natomiast wykształcenie podstawowe (24\%), policealne (18\%) i średnie (17\%).

Pod względem statusu społeczno-zawodowego (ryc. 2B) badani turyści w większości (30\%) prowadzili własną działalność gospodarczą oraz byli rencistami lub emerytami (26\%). W 2013 r. wśród badanych dominowała natomiast grupa osób zatrudnionych na 
umowę (40\%). Tak zmienne w obu badanych latach struktury wieku, wykształcenia oraz typu aktywności zawodowej respondentów wymuszają dbanie o urozmaiconą ofertę turystyczną, atrakcyjną dla zróżnicowanego klienta.

Pod względem długości pobytu oraz miejsca kwaterunku turystów w Krynicy-Zdroju w latach 2013 i 2017 (ryc. 3A) istnieją pewne podobieństwa. Przede wszystkim jest to podobny udział pobytów do tygodnia czasu stanowiących łącznie około połowy przyjazdów. W 2017 r. zwiększył się udział pobytów jednodniowych oraz 8-14-dniowych (każdy o ok. 5\%) w stosunku do 2013 r. Zmniejszyło się natomiast zainteresowanie pobytami dłuższymi niż 2 tygodnie o ok. 11\%. Ten ostatni wynik sugeruje, że pobytu turystów, nawet tych w wieku emerytalnym, nie można jednoznacznie łączyć wyłącznie z turnusami uzdrowiskowymi. Kolejny raz wskazuje to na potrzebę rozwijania kurortu w sposób przedsiębiorczy i nowoczesny, chociażby na podstawie licznych walorów turystycznych, rekreacyjnych czy kulturalnych.

Jako miejsca kwaterunku wśród respondentów najbardziej popularne były pensjonaty (34\% - 2013 r.; 40\% - 2017 r.) (ryc. 3B), które w ciągu ostatnich lat jeszcze bardziej

Ryc. 1. Struktura wieku (A) i płci (B) respondentów w 2017 r.

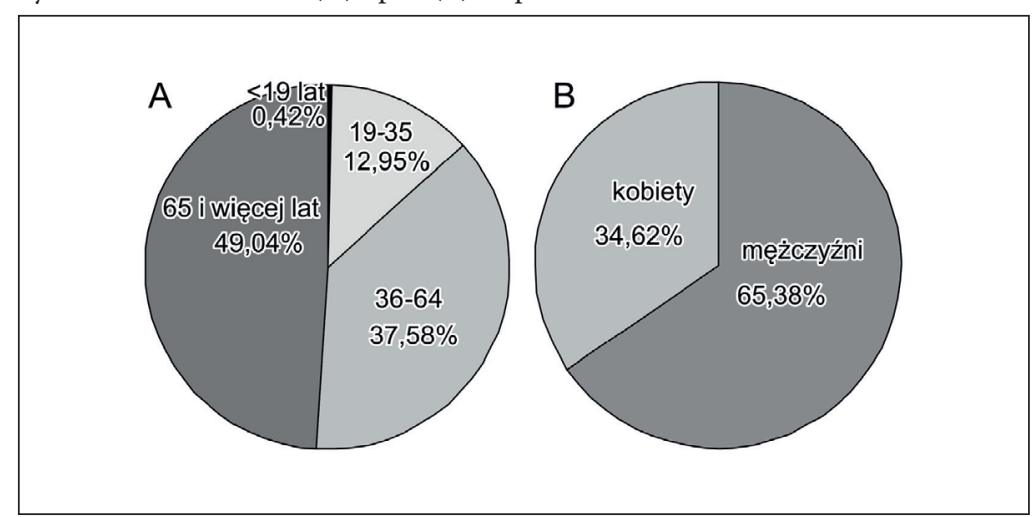

Źródło: opracowanie własne oraz dane z: Dorocki, Borowiec (2014)

Ryc. 2. Struktura wykształcenia (A) i aktywność zawodowa (B) respondentów w 2017 r.
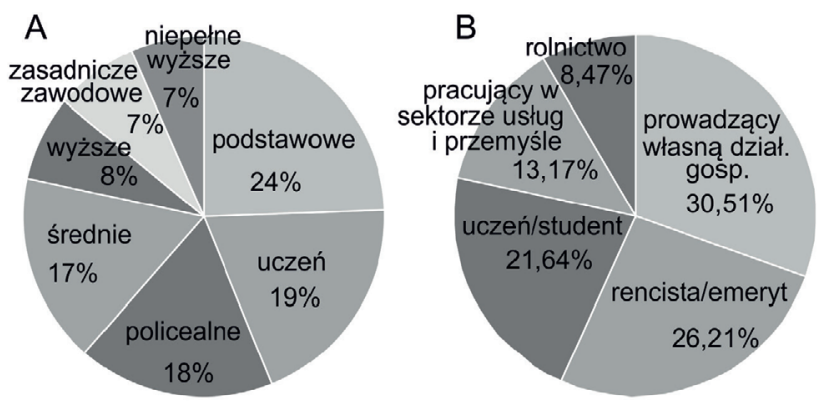

Źródło: opracowanie własne oraz dane z: Dorocki, Borowiec (2014) 
podkreśliły swoją silną pozycję w tym zakresie. Na drugim miejscu w 2017 r. znalazły się hotele - ich udział był większy o 11\% w stosunku do 2013 r. Mniejszym zainteresowaniem cieszyły się natomiast sanatoria (spadek udziału o 14\%), co potwierdza wcześniej wspomniany, malejący udział funkcji typowo uzdrowiskowej Krynicy-Zdroju.

Główne dwa motywy przyjazdu turystów do Krynicy-Zdroju (ryc. 4), którymi są walory wód zdrojowych oraz walory krajobrazowe, nie uległy zmianie na przestrzeni badanych lat, a nawet zajęły dominującą pozycję i pozostały wizytówką oraz cechą charakterystyczną miasta. Pozostałe impulsy odwiedzin Krynicy-Zdroju w 2017 r., ze znacznie już mniejszą liczbą wskazań, to kolejno: odwiedziny znajomych lub rodziny, atrakcyjność bazy noclegowej czy cele biznesowe. Wszystkie one na przestrzeni ostatnich lat zyskały na popularności, wyjątek stanowią jedynie imprezy kulturalne i turystyczne, na które w 2017 r. wskazało o połowę mniej respondentów niż miało to miejsce w 2013 r.

Oprócz walorów naturalnych ważnym czynnikiem przyciągającym turystów do uzdrowiska jest marketing. Najbardziej popularnymi źródłami informacji o Krynicy-Zdroju na przestrzeni ostatnich czterech lat pozostają niezmiennie rodzina i znajomi (2013 r. - 35\%; 2017 r. - 40\%) oraz Internet (2013 r. - 33\%; 2017 r. - 36\%). Innym, coraz bardziej znaczącym źródłem informacji w ostatnich latach staje się telewizja, która zwiększyła swój udział o 5\%.

Turyści zapytani o ogólną ocenę Krynicy-Zdroju w obu badanych latach w zdecydowanej większości oceniali miasto bardzo dobrze i dobrze (ryc. 5). Łącznie było to prawie $90 \%$ odpowiedzi.

Ryc. 3. Długość pobytu (A) oraz miejsca kwaterunku (B) respondentów w 2013 r. i 2017 r.

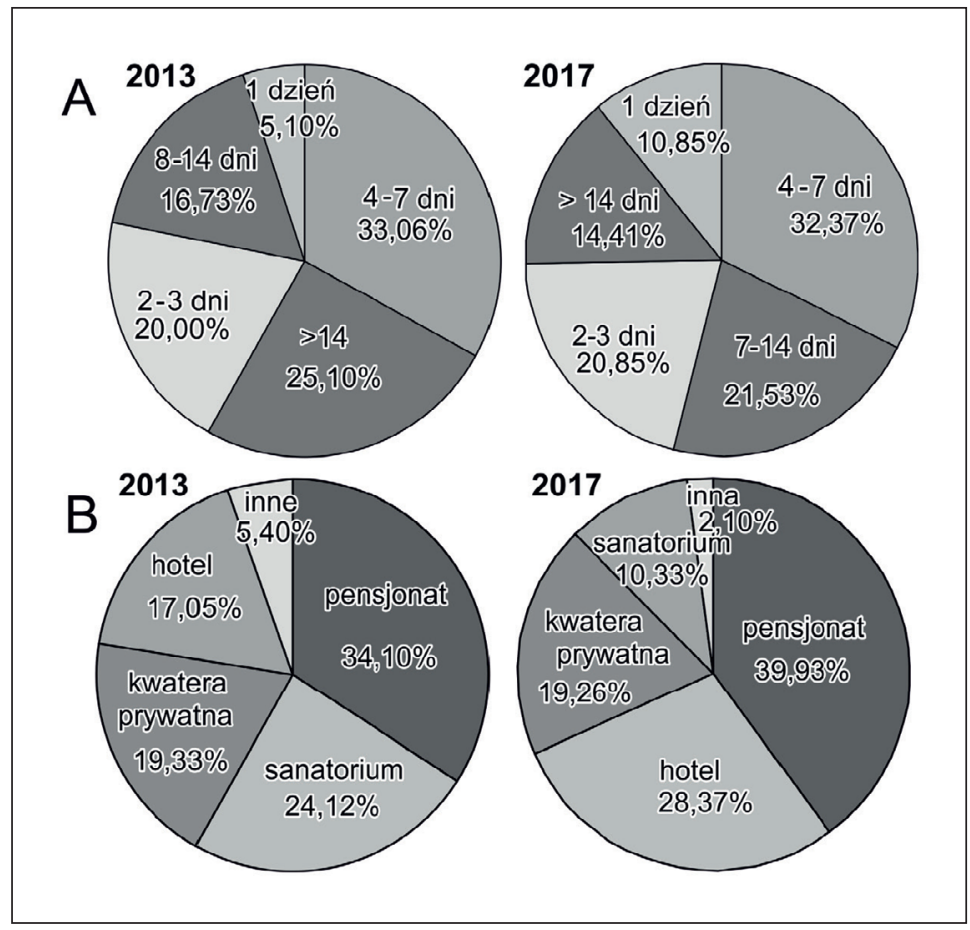

Źródło: opracowanie własne oraz dane z: Dorocki, Borowiec (2014) 
Ryc. 4. Główne impulsy przyjazdu do Krynicy-Zdroju w 2013 r. i 2017 r. (wskazanie respondentów)

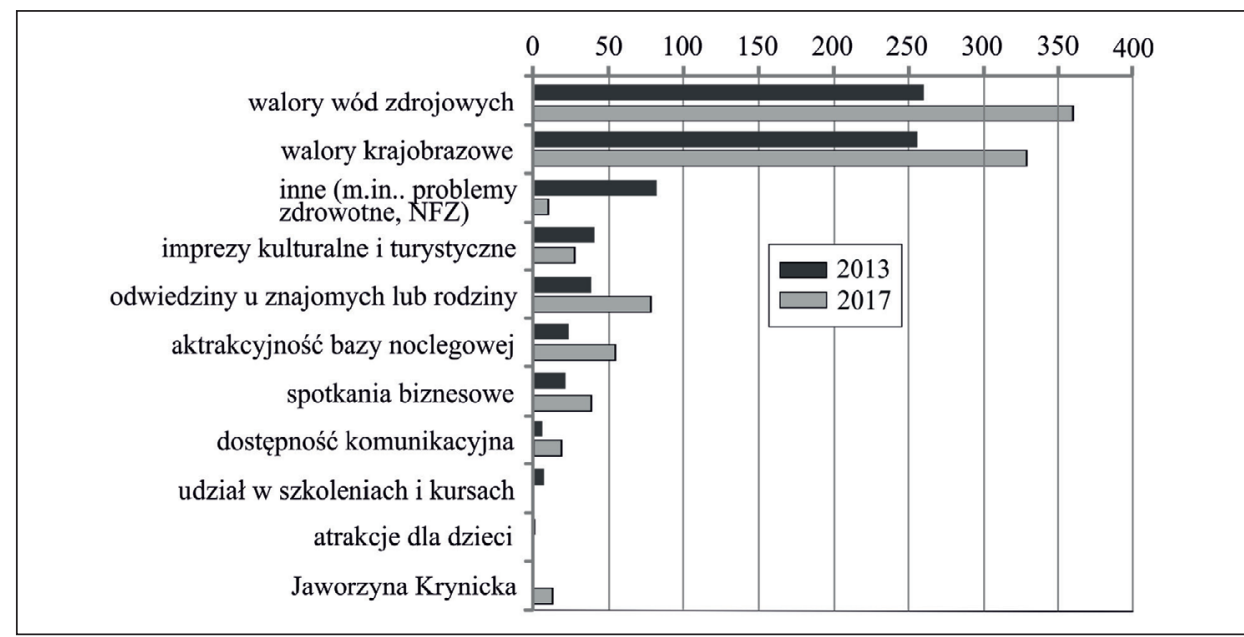

Źródło: opracowanie własne oraz dane z: Dorocki, Borowiec (2014)

Ryc. 5. Ocena Krynicy-Zdroju w 2013 r. i 2017 r.

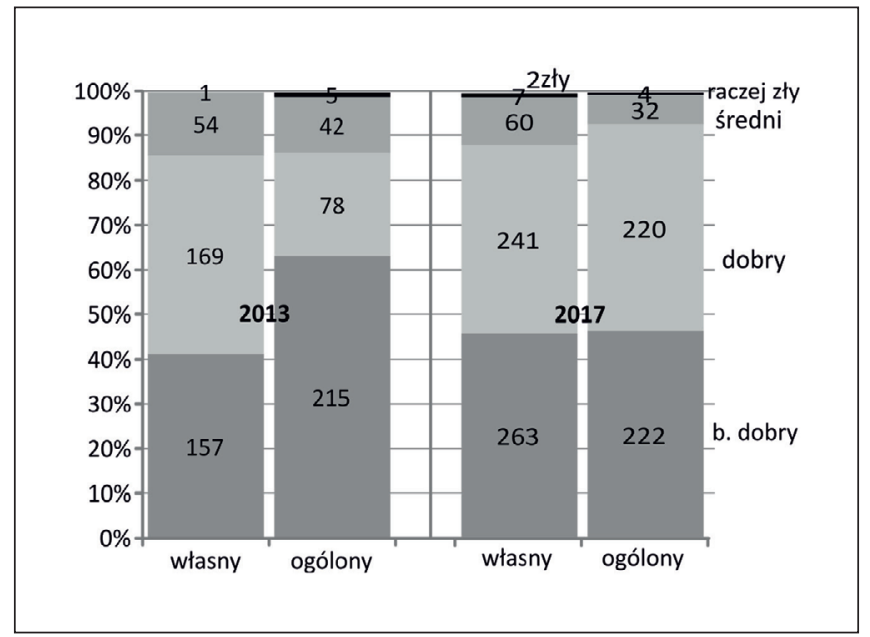

Źródło: opracowanie własne

Wspomniana wyżej wysoka ocena Krynicy-Zdroju ma przełożenie na zwiększające się zainteresowanie ponownym przyjazdem do miasta w roku $2017 \mathrm{w}$ stosunku do roku 2013 (tab. 1). Turyści jako główne powody ponownych odwiedzin wymienili w 2013 r. powietrze, krajobraz i możliwość odpoczynku, a w 2017 r. były to: krajobraz, wody/zabiegi lecznicze oraz możliwości odpoczynku. Głównymi powodami, dla których niewielka grupa turystów już nie będzie chciała powrócić do Krynicy-Zdroju, są niedostateczna liczba rozrywek, rozczarowanie i tłok. Pierwszy wymieniony powód tym bardziej zaskakuje, że akurat opisywane miasto w swojej ofercie ma bardzo różnorodne atrakcje. Dlatego też wydaje się, że badania w tym zakresie powinny być rozszerzone, aby wskazać konkretne deficyty, dla konkretnych grup wiekowych czy struktur turystów. 
Tab. 1. Zainteresowanie ponownym przyjazdem do Krynicy-Zdroju w 2013 r. i 2017 r.

\begin{tabular}{|c|c|c|c|}
\hline \multicolumn{2}{|c|}{2013} & \multicolumn{2}{|l|}{2017} \\
\hline nie, ponieważ & 22 & nie, ponieważ & 58 \\
\hline raz wystarczy & $50 \%$ & nudno, brak rozrywki & $27,78 \%$ \\
\hline tłok, dużo ludzi & $30 \%$ & raz wystarczy & $25,93 \%$ \\
\hline nudno, brak rozrywki & $20 \%$ & jestem rozczarowany & $18,52 \%$ \\
\hline tak, ponieważ & 269 & tłok, dużo ludzi & $11,11 \%$ \\
\hline powietrze & $22,90 \%$ & wysokie ceny & $11,11 \%$ \\
\hline walory krajobrazowe & $22,00 \%$ & brak miejsc zabaw dla dzieci & $5,56 \%$ \\
\hline odpoczynek & $14,30 \%$ & tak, ponieważ & 402 \\
\hline podoba mi się & $11,40 \%$ & walory krajobrazowe & $28,95 \%$ \\
\hline klimat & $8,60 \%$ & wody lecznicze/zabiegi & $22,25 \%$ \\
\hline wody lecznicze/zabiegi & $5,70 \%$ & odpoczynek & $18,50 \%$ \\
\hline miejsce atrakcyjne & $5,70 \%$ & powietrze & $8,04 \%$ \\
\hline stoki narciarskie & $2,90 \%$ & miejsce atrakcyjne & $4,56 \%$ \\
\hline uprzejmi ludzie & $2,90 \%$ & cisza i spokój & $4,56 \%$ \\
\hline podoba mi się region & $2,90 \%$ & uprzejmi ludzie & $3,22 \%$ \\
\hline atrakcje & $2,90 \%$ & atrakcje & $3,22 \%$ \\
\hline tak, ale... & 35 & infrastruktura noclegowa & $3,22 \%$ \\
\hline & & bezpiecznie & $2,14 \%$ \\
\hline & & infrastruktura narciarska & $1,34 \%$ \\
\hline & & tak, ale... & 33 \\
\hline
\end{tabular}

Źródło: opracowanie własne oraz dane z: Dorocki, Borowiec (2014)

Tab. 2. Obszary wymagające interwencji w Krynicy-Zdroju w 2017 r. i 2013 r.

\begin{tabular}{|l|r|r|c|c|}
\hline \multicolumn{1}{|c|}{ Obszary działań } & $\mathbf{2 0 1 7}$ & $\mathbf{2 0 1 3}$ & $\mathbf{2 0 1 7}(\mathbf{\%})$ & $\mathbf{2 0 1 3}$ (\%) \\
\hline Parkingi & 115 & 61 & 22,37 & 42,07 \\
\hline Infrastruktura drogowa (jakość) & 45 & & 8,75 & - \\
\hline Atrakcje (infrastruktura) & 40 & & 7,78 & - \\
\hline Renowacja budynków & 32 & 4 & 6,23 & 2,76 \\
\hline Infrastruktura aktywnego wypoczynku & 30 & & 5,84 & - \\
\hline Likwidacja szyldów reklamowych & 28 & 3 & 5,45 & 2,07 \\
\hline Ograniczenie ruchu komunikacyjnego & 27 & 6 & 5,25 & 4,14 \\
\hline Ład przestrzenny & 26 & & 5,06 & - \\
\hline Place zabaw dla dzieci & 26 & & 5,06 & - \\
\hline Tablice informacyjne & 21 & 3 & 4,09 & 2,07 \\
\hline Ławki & 17 & & 3,31 & - \\
\hline Zieleń & 17 & 10 & 3,31 & 6,90 \\
\hline Kosze na śmieci & 13 & 14 & 2,53 & 9,66 \\
\hline Szlaki turystyczne & 13 & 13 & 2,53 & 8,97 \\
\hline Komunikacja wewnętrzna & 12 & & 2,33 & - \\
\hline Obiekty gastronomiczne & 11 & & 2,14 & - \\
\hline Miejsca dla młodzieży & 10 & 11 & 1,95 & 7,59 \\
\hline Apteki & 7 & & 1,36 & - \\
\hline
\end{tabular}




\begin{tabular}{|l|r|r|r|c|}
\hline Bankomaty & 7 & & 1,36 & - \\
\hline Kawiarenki i ogródki piwne & 5 & 7 & 0,97 & 4,83 \\
\hline Aktywizacja peryferii & 4 & & 0,78 & - \\
\hline Centra handlowe & 4 & & 0,78 & - \\
\hline Punkty turystyczne & 2 & 2 & 0,39 & 1,38 \\
\hline Infrastruktura higieniczna & 1 & 11 & 0,19 & 7,59 \\
\hline Przejścia dla pieszych & 1 & & 0,19 & - \\
\hline Suma & 514 & 145 & 100,00 & 100,00 \\
\hline
\end{tabular}

Źródło: opracowanie własne oraz za: Dorocki, Borowiec (2014)

W celu zbadania obniżonej oceny Krynicy-Zdroju w oczach turystów, czy nawet niechęci do ponownego przyjazdu, poproszono przyjezdnych o wskazanie obszarów „upośledzonych" pod względem funkcjonowania miasta (tab. 2). W obu badanych latach turyści przede wszystkim zwrócili uwagę na niewystarczającą liczbę miejsc parkingowych. Respondenci podawali przykłady dużych hoteli i pensjonatów praktycznie niemających parkingów. Niepokojące jest również wskazywanie na infrastrukturę drogową jako na obszar pilnej interwencji (drugie miejsce w 2017 r.), gdzie cztery lata wcześniej turyści takiego problemu nie dostrzegali. Jednakże wynikać to może z podjętych właśnie w okresie badania prac remontowych, co mogło spowodować negatywne oceny. Inne problemy to niedostateczna infrastruktura związana $\mathrm{z}$ atrakcjami dla przyjezdnych, stan budynków, infrastruktura wypoczynkowa, zbyt duża liczba szyldów reklamowych, zła komunikacja czy brak ładu przestrzennego. Generalnie w 2017 r. turyści chętniej i dokładniej wymieniali obszary miasta niespełniające ich oczekiwań, co może wskazywać na pogorszenie się stanu funkcjonowania miasta lub też większej świadomości i oczekiwań turystów.

\section{Zakończenie}

W rozwoju gospodarczym, przestrzennym i funkcjonalnym Krynicy-Zdroju znaczną rolę odgrywa turystyka. Unikalne walory naturalne oraz bogata i zróżnicowana infrastruktura uzdrowiska zapewniają mu silną przewagę konkurencyjną. Można zaryzykować stwierdzenie, że Krynica-Zdrój stanowi ważny biegun wzrostu gospodarczego dla całego regionu, na co dowody znajdziemy zarówno w badaniach (Borowiec, Dorocki, 2014), jak i w dokumentach strategicznych. Zasoby wód mineralnych oraz ich walory lecznicze stanowią w dalszym ciągu produkt podstawowy w ofercie miasta. Walory zdrojowe i krajobrazowe na przestrzeni lat pozostają głównym impulsem przyjazdów turystów. Jednakże coraz większą rolę w ofercie miasta odgrywają nowe produkty turystyczne, $\mathrm{j}$. turystyka biznesowa oraz wypoczynek i rekreacja, w tym usługi spa i wellness. Walory Krynicy-Zdroju determinują jej marketing terytorialny, który od lat jest stosowany przez samorząd. Wiąże się to z realizacją długiej listy obowiązków i zadań, które gmina uzdrowiskowa musi spełnić, aby zagwarantować zewnętrzne warunki pobytu przyjezdnym gościom i kuracjuszom. Zmiana profilu turysty odwiedzającego uzdrowisko oraz charakter tej wizyty wymuszają bardzo dużą aktywność władz lokalnych. Z przeanalizowanych dokumentów wynika, że władze miasta i gminy zdają sobie sprawę z potrzeby otwarcia się uzdrowiska również na ludzi młodych oraz oraz na osoby poszukujące zróżnicowanych atrakcji i różnorodnych form wypoczynku. Również osoby starsze, jak wynika z ankiet, poszukują w kurorcie rozrywki i atrakcji. Jednocześnie wiele osób oczekuje gotowej 
recepty na atrakcyjny pobyt w Krynicy, przygotowanej oferty imprez oraz odpowiedniej infrastruktury wypoczynkowej.

Główną przyczyną dyskomfortu turystów na przestrzeni lat jest brak parkingów. Problem ten władze gminy starają się ograniczyć przez wprowadzenie płatnych stref parkingowych, jednakże wydaje się, że bez powstania nowych parkingów problem nie zostanie rozwiązany. Zagadnienie to jest symptomem zmian, które zaszły wśród przybywających do Krynicy turystów. Są to ludzie aktywni, mobilni, poszukujący nowych wrażeń i niegodzący się na nudę.

Wydaje się zatem, że znaczenie turystyki w rozwoju gospodarczym Krynicy-Zdroju jak dotąd dość silne będzie jeszcze wzrastać w czasie. Uzdrowisko w ramach tej specjalizacji powinno jednak różnicować swoją ofertę i śledzić zmieniające się trendy na rynku usług turystycznych. Jak wykazano w pracy, pomimo stałości głównych atutów Krynicy w opinii turystów, następują duże zmiany w ich preferencjach i wzroście ich oczekiwań względem funkcjonowania miasta. Na koniec należy zaznaczyć, że Krynica-Zdrój, jak większość dużych ośrodków turystycznych, boryka się z problemem oczekiwań turystów i potrzeb mieszkańców. Pogodzenie tych dwóch, często sprzecznych, postaw może nastąpić jedynie przez rozdzielenie miasta na strefę mieszkalną i turystyczną lub, co wydaje się bardziej racjonalne na ochronę interesów mieszkańców oraz zaspokojenie ich potrzeb, przy równoczesnym procesie rozwoju i modernizacji infrastruktury turystycznej.

Literatura

References

Bajgier-Kowalska, M. (2015). Funkcjonowanie ośrodków spa i wellness w Polsce na przykładzie obiektów komercyjnych i sanatoryjnych w Krynicy-Zdroju. Annales Universitatis Paedagogicae Cracoviensis Studia Geographica, 9, 9-23. DOI:10.24917/3071

Basińska-Zych, A. (2014). Samorząd lokalny jako podmiot tworzący warunki do rozwoju przedsiębiorczości w opinii przedstawicieli branży turystyczno-rekreacyjnej w województwie wielkopolskim. Studia Periegetica, 2(12), 125-149.

Borowiec, M., Dorocki, S. (2014). Rozwój Krynicy-Zdroju jako wynik przedsiębiorczych działań władz samorządowych. Przedsiębiorczość - Edukacja, 10, 267-284.

Brzosko-Sermak, A. (2014). Tourist function in borderlands. 3. Mezinárodní Vědecká Konference Cestovní Ruch, Hotelnictví a Lázeňství ve Světle Vědeckého Výzkumu a Paxe, Karviná 14-15 květen 2014, Slezská univerzita v Opavě.

Brzosko-Sermak, A., Cierniak-Szóstak, E., Karwińska, A., Pawlina, A. (2015). Poszukiwanie rozwiązań dla współczesnych miast. Przykładowe obszary interwencji socjotechnicznych, A. Karwińska (red.), Kraków: Fundacja Uniwersytetu Ekonomicznego w Krakowie.

Brzosko-Sermak, A., Płaziak, M. (2017). Rola dziedzictwa kulturowego i środowiska przyrodniczego w rozwoju miast nadgranicznych Polski wschodniej. Monografia, 548, Politechnika Krakowska.

Buczek, M., Quirini-Popławski, Ł. (2009). Frekwencja kuracjuszy w Krynicy w Karpatach Zachodnich i Truskawcu w Karpatach Wschodnich (Ukraina). Prace Geograficzne, 121, 39-58.

Čuka, P., Dorocki, S., Rachwal, T. (2015). Development of tourism infrastructure in the regions of Central and Eastern Europe. Conference: Innovation Vision 2020: from Regional Development Sustainability to Global Economic Growth, At Amsterdam, Netherlands, Volume: 25, 402-417.

Čuka, P., Dorocki, S., Rachwał, T., Rettinger, R. (2015). Development of ski infrastructure as a factor of local development vs. environmental sustainability: the case of Krynica-Zdroj (Poland). 15th International Multidisciplinary Scientific GeoConference SGEM 2015, SGEM2015 Conference 
Proceedings, ISBN 978-619-7105-41-4 / ISSN 1314-2704, June 18-24, 2015, Book5 Vol. 3, 189-196, DOI: 10.5593/SGEM2015/B53/S21.024

Dorocki, S. (1999). Monografia społeczno-gospodarcza gminy Krynica. Krynica: Urząd Gminy Uzdrowiskowej.

Dorocki, S., Borowiec, M. (2014). Rozwój Krynicy-Zdroju jako wynik przedsiębiorczych działań władz samorządowych. Przedsiębiorczość - Edukacja, 10, 267-284.

Dorocki, S., Brzegowy, P. (2013). Impact of natural resources on the development of spa industry in Krynica-Zdroj. Geoconference on Ecology, Economics, Education and Legislation, SGEM 2013, Vol II, Book Series: International Multidisciplinary Scientific GeoConference-SGEM, 89-96, DOI: 10.5593/SGEM2013/BE5.V2/S21.012,309-316.

Dorocki, S., Brzegowy, P. (2013a). Zarys historii uzdrowiskowej Krynicy w XIX w. W: B. Płonka-Syroka, A. Kaźmierczak (red.), Kultura uzdrowiskowa na Dolnym Śląsku w kontekście europejskim. Tom I, Wrocław: Quaestio, 347-371.

Dorocki, S., Brzegowy, P. (2013b). Szkice z historii uzdrowiskowej Krynicy od fin de siècle’u do końca dwudziestolecia międzywojennego. W: B. Płonka-Syroka, A. Kaźmierczak (red.), Kultura uzdrowiskowa na Dolnym Śląsku w kontekście europejskim. Tom I, Wrocław: Quaestio, 373-390.

Dorocki, S., Brzegowy, P. (2014). Ski and spa tourism as local development strategy - the case of Krynica Zdrój (Poland). Annales Universitatis Paedagogicae Cracoviensis Studia Geographica, 5, 88-116.

Dorocki, S., Brzegowy, P. (2015). Intensyfikacja usług uzdrowiskowych w Polsce po okresie transformacji systemowej. Przedsiębiorczość - Edukacja, 11, 165-176.

Dorocki, S., Brzegowy, P. (2015). Zarys działalności sportowo-turystycznej w Krynicy-Zdroju po roku 1918 i jej wpływ na kształtowanie się uzdrowiskowego klastra turystycznego W: M. Zowisło, J. Kosiewicz (red.), Sport i turystyka w zwierciadle wartości społecznych. Kraków: Akademia Wychowania Fizycznego w Krakowie, 280-288.

Dorocki, S. (2007). Stacja Narciarska „Wierchomla” - lokalny ośrodek aktywizacji gospodarczej. Przedsiębiorczość - Edukacja, 3, 81-87.

Dorocki, S. (2016). Wykorzystanie i stan infrastruktury narciarskiej w gminie Krynica-Zdrój w świetle badań ankietowych. Wyniki badań pilotażowych. Annales Universitatis Paedagogicae Cracoviensis Studia Geographica, 10, 206-222. DOI:10.24917/20845456.10.15

Drygas, D. (2013). Wpływ regulacji prawno-organizacyjnych na sytuację ekonomiczną zakładów lecznictwa uzdrowiskowego w Polsce. Zeszyty Naukowe Uniwersytetu Szczecińskiego. Ekonomiczne Problemy Turystyki, 3(23), 137-151.

Gminny program rewitalizacji Krynicy-Zdroju na lata 2016-2023. (2017). Uchwała Nr XXXIII.227.2017 Rady Miejskiej w Krynicy-Zdroju z dnia 6 marca 2017 r. Pozyskano z: https://bip.malopolska.pl/ umkrynicazdroj,m,292367,program-rewitalizacji.html (dostęp: 2017, 15 października).

Karwińska, A., Brzosko-Sermak, A. (2014). Dobrze funkcjonujące miasto. Koncepcje, cechy, perspektywy rozwoju. Kraków: Uniwersytet Ekonomiczny w Krakowie.

Kopczyńska, D. (2008). Od cieplicy do spa, czyli językowa historia mody na balneoterapię. Poradnik Językowy, 2, 63-69.

Mróz, F. (2016). Sanktuaria kościoła rzymskokatolickiego w przestrzeni sakralnej Polski. W: J. Mokras-Grabowska, J. Latosińska (red.), Kultura i Turystyka. Sacrum i Profanum. Łódź: Regionalna Organizacja Turystyczna Województwa Łódzkiego, 183-203.

Plan rozwoju uzdrowiska Krynicy-Zdroju na lata 2016-2023. (2016). Uchwała Nr XXV.176.2016 Rady Miejskiej w Krynicy-Zdroju z dnia 27 czerwca 2016 r., https://bip.malopolska.pl/umkrynicazdroj/ Article/get/id,1223984.html (dostęp: 2017, 15 października).

Strategia promocji Krynicy-Zdroju. (2011). Uchwała Nr XVIII.115.2011 Rady Miejskiej w Krynicy-Zdroju z dnia 14 grudnia 2011 r., Pozyskano z: https://bip. malopolska.pl/umkrynicazdroj,a,673334,strategia-promocji-gminy-krynicy-zdroju.html.

Strategia rozwoju i promocji małopolskiego produktu uzdrowiskowego na lata 2013-2018. Stowarzyszenie Gmin Uzdrowiskowych RP; publikacja współfinansowana przez Unię Europejską w ramach 
Małopolskiego Regionalnego Programu Operacyjnego na lata 2007-2035, Pozyskano z: http:// www.archiwum.sgurp.pl/images/Strategia\%20Rozwoju\% 20i\%20Promocji\%20MPU.pdf

Strategia rozwoju miasta i gminy Krynica-Zdrój. (2013). Uchwała nr XLIV.252.2013 Rady Miejskiej w Krynicy-Zdroju z dnia 27 czerwca 2013 r. w sprawie przyjęcia „Strategii Rozwoju Gminy Krynicy-Zdroju", http://www.krynica-zdroj.pl/files/fck/File/Strategie/Uch_252_Strategia.pdf (dostęp: 2017, 15 października).

Strategia rozwoju zintegrowanego produktu turystycznego pt. „Perly Doliny Popradu”, opracowana dla sześciu gmin: Krynicy-Zdroju, Łabowej, Muszyny, Piwnicznej-Zdroju, Rytra, Starego Sacza. (2003). Warszawa: Polska Agencja Rozwoju Turystyki.

Wołowiec, T., Reśko, D., (2012). Strategia rozwoju gminy jako narzędzie zarządzania zmianą gospodarczą. Zeszyty Naukowe WSEI. EKONOMIA, 5(2), 61-89.

Agnieszka Brzosko-Sermak, dr, adiunkt w Zakładzie Przedsiębiorczości i Gospodarki Przestrzennej w Instytucie Geografii Uniwersytetu Pedagogicznego w Krakowie. Geograf społeczno-ekonomiczny, socjolog miasta. Członek Polskiego Towarzystwa Geograficznego. Prace: magisterska (2003) i doktorska (2007) w zakresie geografii społeczno-ekonomicznej zostały obronione w Instytucie Geografii i Gospodarki Przestrzennej Uniwersytetu Jagiellońskiego. Europejskie studia w zakresie socjologii miasta, przeprowadzone przez dziewięć uniwersytetów i jednostek badawczych z Europy, zostały zakończone (2007) międzynarodowym tytułem magistra (Master's degree in Comparative Urban Studies). Zainteresowania badawcze autorki ściśle wiążą się z zagadnieniami wpływu położenia miast na: funkcje i ich zmiany, warunki i poziom życia mieszkańców, uwarunkowania rozwoju, użytkowanie ziemi, zarządzanie i współpracę miast, wielokulturowość. Interesują ją również kwestie związane z rewitalizacją miast, panowaniem przestrzennym i partycypacją społeczną. Szczególne zainteresowania badawcze dotyczą miast nadgranicznych i ich uwarunkowań rozwoju.

Agnieszka Brzosko-Sermak, socio-economic geographer, urban sociologist, researcher and lecturer in the Department of Entrepreneurship and Spatial Management, Institute of Geography, the Pedagogical University of Cracow. A member of the Polish Geographical Society. Her MA (2003) and $\mathrm{PhD}$ (2007) theses (both) in socio-economic geography were defended at the Institute of Geography and Spatial Management at the Jagiellonian University in Cracow. She has finished studies in the field of urban sociology organised by nine universities and research institutes from Europe with an international Master's degree (2007) in sociology, geography and political science (Comparative Urban Studies). Her research interests focus on issues of cities, especially: functions, conditions and living standards, conditions of development, land use, management and co-operation of cities, multiculturalism. She is also interested in issues related to urban regeneration, the role of spatial and social participation. Academic research interests include border cities and conditions for their development.

\author{
Adres/Address: \\ Uniwersytet Pedagogiczny im. Komisji Edukacji Narodowej w Krakowie \\ Instytut Geografii \\ Zakład Przedsiębiorczości i Gospodarki Przestrzennej \\ ul. Podchorążych 2 \\ 30-084 Kraków, Polska \\ e-mail: abrzosko@up.krakow.pl
}

Sławomir Dorocki, dr, Uniwersytet Pedagogiczny w Krakowie, Instytut Geografii, Zakład Przedsiębiorczości i Gospodarki Przestrzennej. Absolwent studiów z zakresu geografii społeczno-ekonomicznej Uniwersytetu Pedagogicznego w Krakowie, doktor nauk humanistycznych w dyscyplinie historia (Instytut Europeistyki - Uniwersytet Jagielloński). Adiunkt w Instytucie Geografii Uniwersytetu Pedagogicznego w Krakowie. Zainteresowania badawcze autora skupiają się 
wokół problematyki regionów i procesów regionalizacji społeczno-gospodarczej, ze szczególnym uwzględnieniem zróżnicowania przestrzeni europejskiej oraz procesów integracji europejskiej i uwarunkowań historycznych.

Sławomir Dorocki, PhD, Pedagogical University of Cracow, Institute of Geography, Department of Entrepreneurship and Spatial Management. He has graduated from the Pedagogical University in Cracow with MS degree in Geography, $\mathrm{PhD}$ in History (Institute of European Studies of the Jagiellonian University). Assistant professor at the Pedagogical University of Cracow in the Institute of Geography. His research interests are connected with regional problems and processes of socio-economic regionalisation, with particular emphasis on the diversity of Europe, processes of European integration, and historical conditions.

\section{Adres/Address:}

Uniwersytet Pedagogiczny im. Komisji Edukacji Narodowej w Krakowie

Instytut Geografii

Zakład Przedsiębiorczości i Gospodarki Przestrzennej

ul. Podchorążych 2

30-084 Kraków, Polska

e-mail: sdorocki@up.krakow.pl 